by N. Petit-Maire

\title{
Will greenhouse green the Sahara?
}

The Earth's climatic future lies in (or in between) two contrasting patterns: the continuation of the slow natural processes recorded during the past several million years or the effects of a more recent manmade scenario related to the greenhouse temperature increase, resulting from atmospheric pollution.

In the first case, excluding man's influence, we have a paleoanalogue that could anticipate global changes and the evolution of the north of Africa in the next milleniums. In the second and more probable case, no paleoanalogue exists, because the changes will occur much faster and to a higher level than in any of the past warm temperature phases. Models vary in the estimation of the future greenhouse climate, and the examples of the last glacial-interglacial transition and of the last warm climatic optimum still provide the best presently available, concrete image of the possible greenhouse future of the Saharan and Sahelian belts, as well as its probable pace.

\section{I-The Earth's natural future: a slow, nonlinear trend toward a cold phase, matching, as in the past, an extension of the tropical arid belts at the scale of milleniums}

All oceanic (Ruddiman and others, 1989; Tiedemann and others, 1989), ice (Lorius and others, 1985; Jouzel and others, 1989), and terrestrial (Kukla, 1989) long-term records show that the Earth's climatic parameters have roughly covaried with the astronomical orbital and precessional elements (Berger, 1978) for at least 8 million years. Cold (glacial) phases of low sea level have alternated with warm (interglacial) phases of high sea level, roughly in phase with summer insolation. The changes from the cold to the warm models have been very rapid (a few milleniums), whereas the changes from the warm to the cold scenarios have been slow (about 100,000 years), both processes being nonlinear and marked by abrupt events (Duplessy and others, 1986).

In tropical belts that are characterized by steep rainfall gradients ( $1 \mathrm{~mm} / 1.4 \mathrm{~km}$ to the north, according to Moore, 1990), and in good conformity with the models (Kutzbach, 1981; Kutzbach and StreetPerrott, 1985), wide latitudinal shifts of the isohyets fit these variations that are related to the velocity of the general circulation (Leroux, 1988) and to the production of water-vapor over the equatorial oceans (Tiedemann and others, 1989). These variations induce differences in the activity and range of the monsoonal summer rains: during the last glacial maximum at $18 \mathrm{ka}$, the boundary between the Sahara and the Sahel was 300 to $400 \mathrm{~km}$ south of its present location, as evidenced by paleodunes (Sarnthein, 1978; Talbot, 1984) and vegetation changes (Lézine, 1989).

The summer insolation curve has decreased sharply for about 9,000 years, and the Earth heads irregularly toward a new glacial phase, the first important cold peak estimated at $5 \mathrm{ka}$ after present (Berger and Tricot, 1986, fig. 1). The present, astronomically forced situation is thus one of already degraded climatic conditions, relative to the last warm optimum. This trend is evident at both global and local levels: in the last $6 \mathrm{ka}$, the global sea-surface temperature has lowered by about $4{ }^{\circ} \mathrm{C}$ (Lorius and others, 1985; Jouzel and others, 1989) and glaciers have advanced (An and others, 1989; Jorda, 1983), while the $100-\mathrm{mm}$ isohyet in the north of Africa has shifted at least $500 \mathrm{~km}$ southward of its early Holocene location (Haynes and Mead, 1987; Petit-Maire and Riser, eds., 1983; Petit-Maire and others, 1987; Petit-Maire, 1986, 1989; Lézine, 1989; Neumann. 1989; Pachur and Kröpelin, 1989).

History records the social and economic effects of this aridification all along the Afro-Asian arid belt: for example, the declines of the sub-Saharan empires, Egypt, the north African Roman colonies, Anatolia, Mesopotamia (Roberts, 1989), and of the silk road along the Takla Makan desert in southwestern China, were due mainly to these climatic changes (Butzer, 1982; Issar, 1990). Man has been, for some 2,000 years, a powerful ally to the long-term astronomical trend, through land degradation resulting from uncontrolled demographic increase, and the consequent overcultivation, overstocking. and overuse of water-resources. "Good" (wet) and "bad" (dry) short periods, recorded in myths or history, underlie the slow global evo-

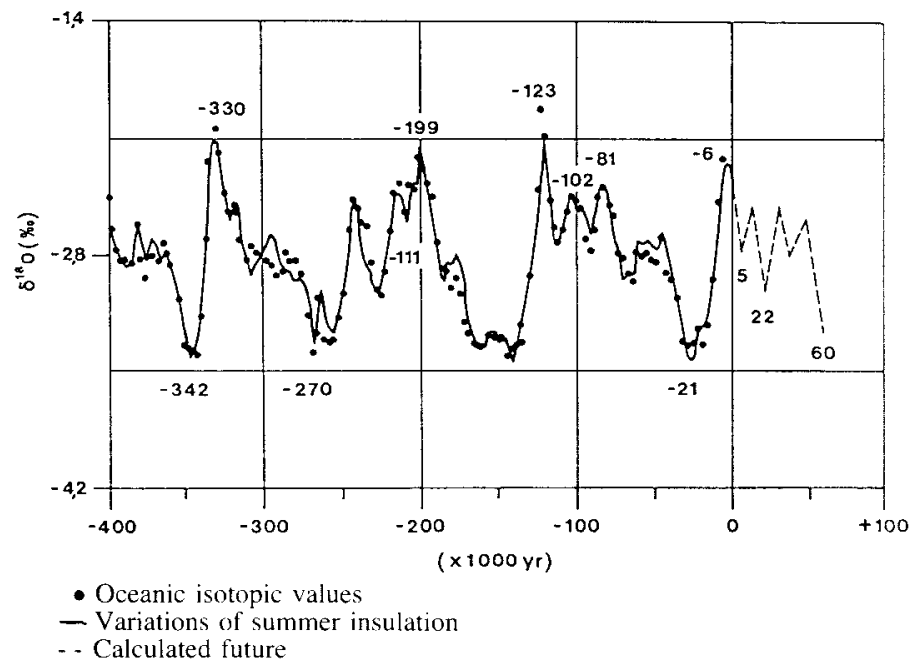

Figure 1. - Long-term climatic variations over the past 400,000 years and a prediction for the next 60,000 years. Taken from Berger and Tricot (1986). 
lution, and they have modulated the climate at the human scale of decades or centuries, through still-unexplained Sea Surface Temperature (SST) anomalies (Folland and others, 1986), probably in relation with short-term (11, 22 years) periodicities of solar activity (Rozelot, 1989: Bücher, 1989; Ribes and others, 1988, 1989). The vegetal and animal species in climatically fragile semiarid and arid areas are normally adapted to such short periodicities. but their resilience is now impeded by the manmade deterioration of their biotopes. Thus, in the improbable case of an undisturbed future evolution, man would enhance the slow pace of orbital changes, which result from astronomically forced cooling, toward an increase in aridity in the monsoonal-dependent areas. The natural situation we should reach through several irregular, abrupt climatic changes over several milleniums might correspond to the maximal cold situation shown in figure 2, that is, a drastic deterioration of these areas, similar to the deterioration that was reached around $18 \mathrm{ka}$.

\section{II-An eventual greenhouse future: a possible increase in monsoonal activity over the Sahel and southern Sahara and consequent environmental changes at the scale of centuries}

The rise in greenhouse gases generated by man, after these gases decreased naturally from the end of the last climatic optimum at some $6 \mathrm{ka}$, has no match in the known Quaternary records. The present carbon dioxide $\left(\mathrm{CO}_{2}\right)$ values of 348 parts per million by volume (ppmv) and methane $\left(\mathrm{CH}_{4}\right)$ values of 1,700 parts per billion by volume (ppbv) have already exceeded the $280 \mathrm{ppmv}$ and $650 \mathrm{ppbv}$ measured, respectively, in Vostok Antarctic ice during the recent interglacial periods (Chapellaz and others, 1990). The evaluation of the climatic changes expected in the coming decades, as a result of still-higher ratios of these gases. is in progress, and several models have been produced. The models vary as to the effects anticipated on the northern tropical belt in Africa.

In Stouffer and others' (1989) simulation for a $\mathrm{CO}_{2}$ increase of 1 percent per year, the thermal inertia is lower in the Northern Hemisphere than in the southern one, which results in a warming of surface air that increases with latitude. The ocean warming, essentially confined to the upper water layer, also increases with latitude. According to this model, at about $10^{\circ} \mathrm{N}$. . surface air will be $1{ }^{\circ} \mathrm{C}$ warmer after 35 years and $2{ }^{\circ} \mathrm{C}$ warmer after 65 years, which may he significant in terms of water-vapor production over the Atlantic Ocean.

Washington and Meehl (1989) performed an experiment that coupled a coarse-grid general circulation model of the ocean with a global, spectral general circulation model of the atmosphere. In this model. $\mathrm{CO}_{2}$ gradually increases at a linear rate of 1 percent per year. Most SST changes for 26-30 years $\left(\mathrm{CO}_{2}\right.$ amount having increased 30 percent) are confined to the surface layer of water and have maximums of warming near $20^{\circ} \mathrm{N}$. and $45^{\circ} \mathrm{S}$. At the same time, surface air temperatures show significant warming over northwestern Africa for a globally averaged increase of $0.7^{\circ} \mathrm{C}$ (versus $1.6^{\circ} \mathrm{C}$ in the case of a $\mathrm{CO}_{2}$ instantaneous doubling model). However, the authors note a tendency of this ocean model to produce tropical SSTs that are too cold.

Santer and others (in press) calculated an average result for precipitation from the existing general circulation models. The increase in summer rainfall is very high $(\Delta \mathrm{P}=0.5 \mathrm{~mm} /$ day $)$ between $10^{\circ} \mathrm{N}$. and $30^{\circ} \mathrm{N}$., especially on the southern Sahel. Unfortunately, the standard deviation between all models is $0.6 \mathrm{~mm} /$ day for this period and area, which hinders any valuable interpretation of the analysis.

Thus, the models generally anticipate some warming of the tropical oceans, even if the warming is quite moderate. If one considers moreover a weakening of wind strength, increases in monsoonal activity and range should occur (Leroux, 1988), as they have in past cold to warm temperature shifts (Kutzbach, 1987), and bring about significant environmental changes in the position of the Saharan and Sahelian belts. As proposed by Washington and Meehl (1989), these climatic variations and the resulting environmental changes most probably will take place at the same secular time scale as during the last deglaciation and at the onset of the last climatic optimum. This time scale would result from the large thermal inertia and from the superimposition of many still-unknown natural factors other than greenhouse gases. An approximate paleoanalogue for these first moderate effects in the north of Africa could be the 9.5-8.5 ka period, as modeled by COHMAP (1988) and confirmed by field evidence.

The two steps of the last deglaciation (Duplessy and others, 1986; Mix and Ruddiman, 1985) touched the present Sahara with different intensities and time lags, according to the geographic position. The first (late Pleistocene) step induced precipitation over the high areas of the central Sahara (Tibesti and Hoggar) and the oceanic borders of the Sahara (thin paleosols are observed in dunes along the south Moroccan coast and in the eastern Canary Islands). At the same time, no significant climatic change occurred in the most arid isolated areas near the Tropic of Cancer (such as the Taoudenni basin in northern Mali or the Gilf Kebir in Egypt) before approximately 9 ka (Faure, 1969; Rognon, 1980; Petit-Maire and others, 1987; Kröpelin, 1987; Fabre and Petit-Maire. 1988; Petit-Maire, 1986. 1989; Pachur and Kröpelin, 1989).

The Holocene climatic change in the Sahara probably began with modifications in coastal morphology. Between 9.5 and $8.5 \mathrm{ka}$, a very abrupt sea level rise of $28 \mathrm{~m}$ (Fairbanks, 1989) may have been felt even at human scale. It flooded the settlements established by epipaleolithic man on the still-emerging areas of the continental shelf at the foot of the high windy cliffs at Tarfaya (southern Morocco). Middens bearing human remains and the cold-water Molluscs Amygdala decussata (Tapes), dated from 10.5 to 7.86 ka (Grebenart, 1975; Petit-Maire, 1980), there bring evidence of retreat inland and further migration to more hospitable sites. If a new thermic expansion of the oceans occurred and was accentuated by ice melting, the low Atlantic coast of the Sahara, between the Senegal estuary and the Rio de Oro peninsula, might be flooded by saltwater, and the coastal freshwater wells used by nomadic groups would become unfit for consumption by humans and cattle.

During some 500 years $(9.0-8.5 \mathrm{ka})$, changes in surface hydrology were spectacular throughout the Sahara from the Atlantic Ocean to the Red Sea. At 8.5 ka, freshwater lakes and swamps, fed by rising aquifers and local runoff, appeared widely in the topographical depressions and in the troughs between the dunes built during the late Pleistocene cold, arid phase. At $23^{\circ} \mathrm{N}$. in Mali, lakes were permanent from $8.3 \mathrm{ka}$ on, despite the total lack of water-input from other than the small local basin and despite the low latitude (Fabre and Petit-Maire, 1988). Sudanian and Sahelian vegetal and animal species reached, respectively, $20^{\circ} \mathrm{N}$. and $23^{\circ} \mathrm{N}$. at $8.5 \mathrm{ka}$, with local variations due to geographical position (Brookes. 1983; PetitMaire and Riser, eds., 1983; Petit-Maire, 1986, 1989; Schulz, 1987; Neumann. 1989; Van Neer and Uerpmann, 1989). Paleosols confirm that a steppic Gramineae cover existed, at least locally, even in the extant Tanezrouft hyperdesertic area (Petit-Maire and others, 1990) during the climatic optimum. However, radiocarbon dating of archeological sites in western Sahara shows that neolithic man populated the area only after $7.0 \mathrm{ka}$, probably following the migration of large game. 


\section{PAST CLIMATIC SITUATIONS}

\section{A KEY TO THE FUTURE}

\section{PRESENT SITUATION}

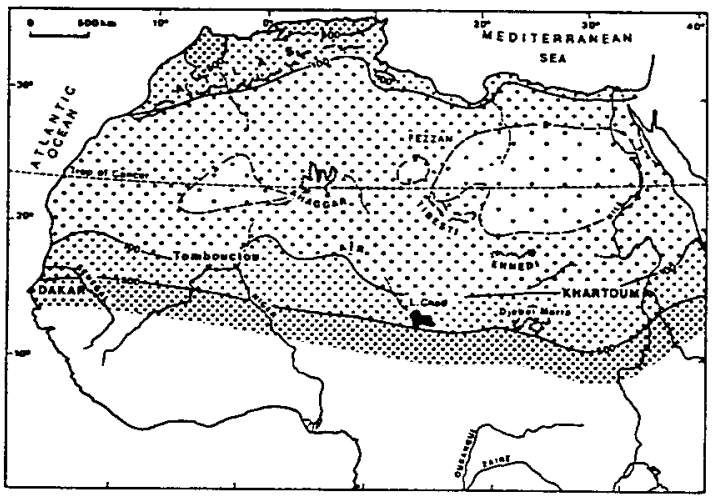

Mean annual precipitations

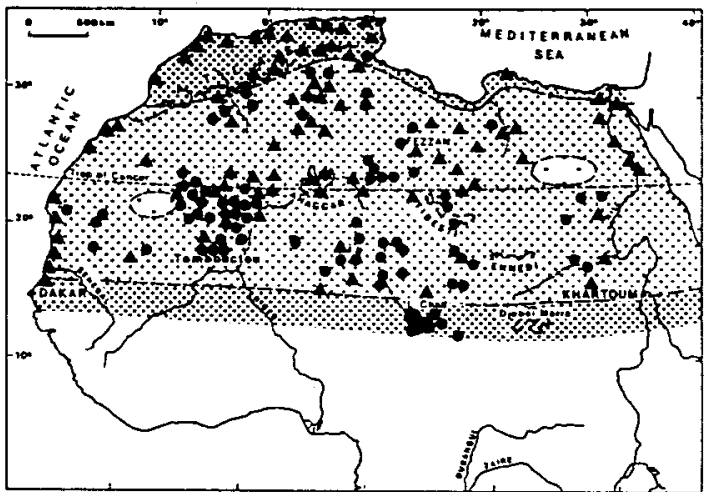

$8 \mathrm{ka}$ (INTERGLACIAL SITUATION)

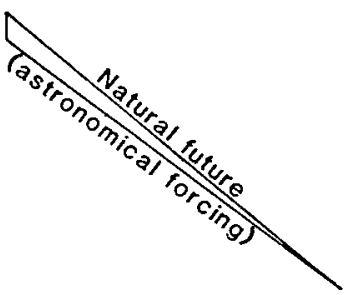

$\because \because<5 \mathrm{~mm} \quad \because 6-100 \mathrm{~mm} \quad \because 100-500 \mathrm{~mm}$

\%承

$500 \mathrm{~mm}$ A Archaeological sites

- Lake deposits

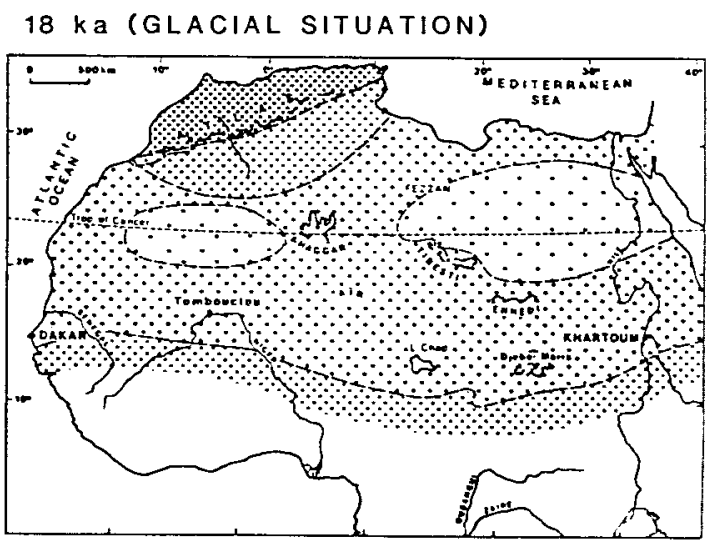

Figure 2.-Approximate climatic situations in the north of Africa at present, at $8 \mathrm{ka}$, and at $18 \mathrm{ka}$.

At the geological scale, the change in biomass between $17^{\circ} \mathrm{N}$. and $24^{\circ} \mathrm{N}$. within, at the most, two milleniums (9-7 ka) was incredibly rapid. This is illustrated strikingly by the paleoenvironmental map of northern Mali (presently an hyperdesertic area) at $8.0 \mathrm{ka}$ (Petit-Maire and Riser, 1988). It is easier to conceive if one considers that, in semiarid to arid areas, the tree-shrub savanna may regenerate in some 2.5 years after a period of severe drought (Le Houérou, 1989). Moreover, all persons familiar with arid environments know how fast the desert can bloom and green after a rainy period, owing to the high resilience of "dormant" annual herbaceous species that are adapted to the irregularity of the summer monsoonal rainfall.

Thus, in the eventuality of a greenhouse rise of equatorial SSTs and of monsoonal activity and range, we may expect, as in the past, a retraction of the Saharan biotopes northward, to the benefit of Sahelian vegetation and animal life. However, the example of the last such shift also clearly shows that, contrary to sea level rise, such changes cannot be expected to occur in the span of a few decades. but rather within centuries and with important local variations. Still, one could expect the present Sahara to recover a "green" aspect with relative rapidity because land degradation would not there slow up the effects of climatic change upon the environment by cutting, trampling, and pasturing the regenerating biotopes, as occurs in the Sahel. Besides, no wide-leaved vegetation would be there to impede, through evapotranspiration, the recharge of local aquifers that, in some favorable areas, would outcrop relatively fast, as happened at some $9 \mathrm{ka}$. Therefore, a relatively better response could be expected in areas that are presently deserts.

\section{Conclusions}

$W_{\text {ill nature slowly, at the scale of several milleniums, extend again }}$ the tropical deserts southward, or will the increase of radioactive gases green the deserts on a much shorter. secular time scale?

The warm $\mathrm{CO}_{2}$ spell is given as inevitable by most authors. The rise of $\mathrm{CH}_{4}$ in the last 300 years at 2.5 times its past interglacial values (Chapellaz and others, 1990) is still more alarming because it has, per mole, a warming potential 3.7 times that of $\mathrm{CO}_{2}$ (Lashof and Ahuja, 1990). Considering the increases of industrial emissions. fermenting garbage accumulations, cattle and rice paddies throughout the whole world, a reduction in methane cannot be expected in the future.

"La Nina" strong cooling in 1988 did not break the warm trend (Kerr, 1990) that has been evidenced by all the temperature curves during the last 50 years. Records from Pic du Midi Observatory 
show that the mean annual temperature in this nonpolluted environment at $2,800 \mathrm{~m}$ altitude increased $0.82^{\circ} \mathrm{C}$ between 1882 and 1970 . There the difference between maximum and minimum daily temperatures decreased from 8.06 to $5.53{ }^{\circ} \mathrm{C}$ during the same period because of a sharp $\left(+2.09{ }^{\circ} \mathrm{C}\right)$ increase observed in all seasons in the minimum daily temperature (Bücher and Dessens, in press).

According to Flohn (1989), we already have entered the greenhouse scenario: the evaporation over the tropical oceans has increased by some 15 percent in the last 30 years and is responsible for severe anomalies, such as intensified El Ninos and winter extratropical cyclones above the North Pacific and North Atlantic Oceans. The frequency of these storms will increase progressively, even if the temperature rise of $4 \pm 1{ }^{\circ} \mathrm{C}$ expected for the next 50 years will be much less at low latitudes (Manabe and Wetherald, 1980). Are the "unprecedented oddities, prodigious number of meteorological singularities, the high flooding of the foreshore areas and the tidal surges overtopping the sea-defenses" recorded in the last decade (Watts, 1990) mere oddities in the general run of weather patterns, or do they reflect Flohn's hypothetical abrupt greenhouse change?

Flohn's (1989) proposition is the most probable. We must expect the occurrence of the warm greenhouse scenario, already predicted by Arrhenius in 1896 at the onset of the industrial age. Decisionmakers must urgently and actively consider our near future, at least at the scale of the last Holocene warming. Even if the only process that a young man now living in the Sahara could possibly witness is a rapid sea level rise along the Mauretanian shores, even if the habitability of present deserts is not a fact of the coming century, the time to prepare for such changes is still now. Desert development programs could take advantage of known paleodrainages and paleolakes: their still-existing geological and sedimentological features, (impervious clays, and ancient channels) could be used to direct eventual floods or meteoric waters rapidly into newly engineered areas, rather than let the water spread out at random. Again, the time to prepare for climatic change is NOW.

\section{Acknowledgments}

I warmly thank André Berger for his friendly suggestions and for the information he provided. I also thank Marcel Leroux and Jöel Guiot for their helpful advice, as well as Carol Breed and John McCauley, who encouraged me to board this risky ship.

\section{References}

An Zhisheng, Wu Xihao, Lu Yanchou, Zhang De'er, and Song Xianjun, 1989, Paleoenvironmental changes in China during last 18,000 years: International Geological Congress, 28th, Washington, D.C., 1989, Abstracts, v. 1, p. 38-39.

Arrhenius, S., 1896, On the influence of carbonic acid in the air upon the temperature of the ground: The London, Edinburgh, and Dublin Philosophical Magazine and Journal of Science, 5th series, v. 41, p. $237-276$.

Berger, A.L., 1978. Long-term variations of daily insolation and Quaternary climatic changes: Journal of Atmospheric Sciences, v. 35, p. 2362-2367.

Berger, A.L., and Tricot, C., 1986, Global climatic changes and astronomical theory of paleoclimates, in Cazenave, A., ed., Earth rotation: Solved and unsolved problems: Dordrecht, Reidel Publishing Co., p. $111-129$

Brookes, I.A., 1983, Dakhleh Oasis: A geoarchaeological reconnaissance: Society for the Study of Egyptian Antiquities Joumal, v. 13, p. 167-187.

Bücher, A., 1989, Cycles solaires et phénomènes terrestres, in Bücher, A. ed., [Réunion] IGCP 252, Variations astronomiques et changements climatiques terrestres, Bagnères-de-Bigorre, France, September 1988: Conseil régional de Midi-Pyrénées, 14 p.
Bücher, A., and Dessens, J., in press, Secular trend of surface temperatures at an elevated observatory in the Pyrenees.

Butzer, K.W., 1982, Archaeology as human ecology: Cambridge, UK, Cambridge University Press, $380 \mathrm{p}$

Chapellaz, J., Barnola, J.M., Raynaud, D., Korotkevich, Y.S., and Lorius, C., 1990, Ice record of atmospheric methane over the past 160,000 years: Nature. v. 345, p. $127-131$.

COHMAP (Cooperative Holocene Mapping Project) members, 1988, Climatic changes of the last 18,000 years: Observations and model simulations: Science, v. 241, p. 1043-1052

Duplessy, J-C., Arnold, M., Maurice, P., Bard, E., Duprat, J., and Moyes, J., 1986, Direct dating of the oxygen-isotope record of the last deglaciation by ${ }^{14} \mathrm{C}$ accelerator mass spectrometry: Nature, v. 320 , p. $350-352$.

Fabre, J., and Petit-Maire, N., 1988, Holocene climatic evolution from two palacolakes near Taoudenni, Mali $\left(22^{\circ}-23^{\circ} \mathrm{N}\right)$ : Palaeogeography, Palaeoclimatology, Palaeoecology, v. 65, p. 133-148.

Fairbanks, R.G., 1989, A 17,000 year glacio-eustatic sea level record: Influence of glacial melting rates on the younger Dryas event and deep-ocean circulation: Nature, v. 342, p. 637-642.

Faure, H., 1969, Lacs quaternaires du Sahara: Mitteilungen Internationale Vereinigung für Theoretische und Angewandte Limnologie, v. 17, p. 13l-146.

Flohn, H, 1989, Andert sich unser Klima?, in Mannheimer Forum 88/89: Mannheim, FRG, Boehringer, p. 135-189.

Folland, C.K., Palmer, T.N., and Parker, D.E., 1986, Sahel rainfall and worldwide sea temperatures 1901-85: Nature, v. 320, p. 602-607.

Grebenart, D., 1975, Matériaux pour l'étude de l'Epipaléolithique et du Néolithique du littoral du Maroc saharien, in L'Epipaléolithique méditerranéen, 1st, Aix-en-Provence, 1972, Actes du Coloque: Paris, Centre National de la Recherche Scientifique, p. 151-188.

Haynes, C.V., and Mead, A.R., 1987, Radiocarbon dating and paleoclimatic significance of subfossil Limicolaria in northwestern Sudan: Quaternary Research, v. 28 , p. 86-99.

Issar, A.S., 1990, Water shall flow from the rock: New York, SpringerVerlag, $213 \mathrm{p}$.

Jorda, M., 1983, L'evolution glaciaire d'altitude dans les Alpes françaises du Sud au cours des 15 derniers millénaires, in Schroeder-Lanz, H., ed., Late- and postglacial ossilations of glaciers: Glacial and periglacial forms, Colloquium, Trier, FRG, 1980: Rotterdam, A.A. Balkema Publishers, p. 35-56.

Jouzel, J., Raisbeck, G., Benoist, J-P., Yiou, F., Lorius, C., Raynaud, D., Petit, J.R., Barkov, N.I., Korotkevich, Y.S., and Kolyatkov, V.M., 1989, A comparison of deep Antarctic ice cores and their implications for climate between 65,000 and 15,000 years ago: Quaternary Research, v. 31 , p. $135-150$.

Kerr, R.A., 1990, Global warming continues in 1989: Nature, v. 247. p. 521.

Kröpelin, S., 1987, Palaeoecological evidence from early to mid-Holocene playas in the Gilf Kebir (S.W. Egypt): Palaeoecology of Africa and of the Surrounding Islands and Antarctica, v. 18, p. 189-208.

Kukla, G., 1989, Loess stratigraphy in central China: Palaeogeography, Palaeoclimatology, Palaeoecology, v. 72, p. 203-225.

Kutzbach, J.E., 1981, Monsoon climate of the early Holocene: Climate experiment with the Earth's orbital parameters for 9,000 years ago: Science, v. 214 , p. $59-61$.

1987. The changing pulse of the monsoon, in Fein, J., and Stephens, P., eds., Monsoons: New York, John Wiley, p. 247-258.

Kutzbach, J.E., and Street-Perrott, F.A., 1985, Milankovitch forcing of fluctuations in the level of tropical lakes from 18 to 0 Kyr B.P.: Nature, v. 317, p. $130-134$.

Lashof, D.A., and Ahuja, D.R., 1990, Relative contributions of greenhouse gases emissions to global warming: Nature, v. 344 , p. 529-531.

Le Houérou, H.Q., 1989, The grazing land ecosystems of the African Sahel: New York, Springer-Verlag, Ecological Studies no. 75, 282 p.

Leroux, M., 1988, La variabilité des précipitations en Afrique occidentale: Les composantes aérologiques du problème: Office de la Recherche Scientifique et Technique Outre-Mer, Veille climatique satellitaire, no. 22 , p. $26-65$.

Lézine, A-M., 1989, Late Quaternary vegetation and climate of the Sahel: Quaternary Research, v. 32, p. 317-334. 
Lorius, C., Jouzel, J., Ritz, C., Merlivat, L., Barkov, N., Korotkevich, Y., and Kolyatkov, V., 1985, A 150,000 year climatic record from Antarctic ice: Nature, v. 316, p. 591-596.

Manabe, S., and Wetherald, R.T., 1980, On the distribution of climate change resulting from an increase in $\mathrm{CO}_{2}$ content of the atmosphere: Journal of Atmospheric Sciences, v. 37, p. 99-118.

Mix, A.C., and Ruddiman, W.F., 1985, Structure and timing of the last deglaciation: Oxygen-isotope evidence: Quaternary Science Reviews, v. 4 , p. $59-108$

Moore, P.D., 1990. Ups and downs in the Sahel: Nature, v. 343, p. 414.

Neumann, K., 1989, Vegetations geschichte der Ost Sahara in Holözan, in Kuper, R., ed., Forschungen zur Umweltgeschichte der Ostsahara, v. 2 of Africa praehistorica: Köln, Heinrich-Barth Institut, p. 13-182.

Pachur, H.J., and Kröpelin, S., 1989, L'aridification du Sahara oriental à l"Holocène moyen et supérieur: Bulletin de la Societé Géologique de France, 8th series, v. 5, p. 99-107.

Petit-Maire, N., 1980, Holocene biogeographical variations along the northeastern African coast $\left(28^{\circ}-19^{\circ} \mathrm{N}\right)$ : Palaeoclimatic implications, in Sarnthein, M., Seibold, E., and Rognon, P., eds., Sahara and the surrounding seas: Sediments and climatic changes: Palaeoecology of Africa and of the Surrounding Islands and Antarctica, v. 12, p. 365-377.

1986, Paleoclimates in the Sahara of Mali: A multidisciplinary study: Episodes, v. 9, p. 7-16

1989, Interglacial environments in presently hyperarid Sahara: Paleoclimatic implications, in Leinen, M., and Sarnthein, M., eds., Palaeoclimatology and palaeometeorology: Modern and past patterns of global atmospheric transport: Dordrecht, Kluwer Academic Publishers, p. $637-661$.

Petit-Maire, N., Commelin, D., Fabre, J., and Fontugne, M., 1990, First evidence for Holocene rainfall in the Tanezrouft hyperdesert and its margins: Palaeogeography, Palaeoclimatology, Palaeoecology, v. 79, p. 333-338.

Petit-Maire, N., Fabre, J., Carbonel, P., Schulz, E., and Aucour, A-M., 1987, La dépression de Taoudenni (Sahara malien) à l'Holocène: Géodynamique, v. 2, p. 61-67.

Petit-Maire, N., and Riser, J., eds., 1983, Sahara ou Sahel? Quaternaire récent du bassin de Taoudenni (Mali): Marseille, Imprimerie Lamy, $437 \mathrm{p}$.

Petit-Maire, N., and Riser, J., 1988, Le Sahara à l'Holocène: Mali: Paris, Commission de la Carte Geologique du Monde, Institut Géographique National, 1 Map 1:1,000,000.

Ribes, E., Merlin, P., Ribes, J-C., and Barthalot, R., 1989, Absolute periodicities in the solar diameter, derived from historical and modern data: Annales Geophysicae, v. 7, p. 321-330.

Ribes, E., Ribes, J-C., Vince, I., and Merlin, P., 1988, Sur l'oscillation du diamètre solaire: Comptes Rendus de l'Academie des Sciences, 2nd series, v. 307, p. 1195-1201.

Roberts, N., 1989, The Holocene: Oxford, Blackwell Scientific Publications, $227 \mathrm{p}$.

Rognon, P., 1980, Interprétation paléoclimatique des changements d'environnements en Afrique du Nord et au Moyen-Orient durant les 20 derniers millénaires: Palaeoecology of Africa and the Surrounding Islands and Antarctica, v. 13, p. 21-44.

Rozelot, J-P., 1989, Essai de reconstitution des cycles d'activité solaire et climat terrestre, in Bücher, A., ed., [Réunion] IGCP 252, Variations astronomiques ct changements climatiques terrestres, Bagnères-deBigorre, France, September 1988: Conseil régional de Midi-Pyrénées, $30 \mathrm{p}$.
Ruddiman, W.F., Sarnthein, M., Backuran, J., Baldauf, J.G., Curry, W., Dupont, L.M., Janecek, T., Pokras, E.M., Raymo, M.E., Stabell, B., Stein, R., and Tiedemann, R., 1989, Proceedings of the Ocean Drilling Program, scientific results: College Station, Texas, Texas A\&M University, v. 108 , p. 463-484.

Santer, B., and others, in press, Multivariate methods for the detection of greenhouse gas-induced climate change, in Schlesinger, M., ed., Greenhouse Gas Induced Climatic Change, symposium, Amherst, Massachusetts, USA, 1989, Proceedings: New York, Elsevier.

Sarnthein, M., 1978, Sand deserts during glacial maximum and climatic optimum: Nature, v. 272 , p. $43-46$.

Schultz, E., 1987, Die Holozäne vegetation des Zentralen Sahara (N. Mali, N. Niger, W.S. Libya): Palaeoecology of Africa and of the Surrounding Islands and Antarctica, v. 18, p. 143, 161.

Stouffer, R.J., Manabe, S., and Bryan, K., 1989, Interhemispheric asymmetry in climate response to a gradual increase of atmospheric $\mathrm{CO}_{2}$ : Nature, v. 342 , p. $660-662$.

Talbot, M.R., 1984, Late Pleistocene rainfall and dune building in the Sahel: Palaeoecology of Africa and of the Surrounding Islands and Antarctica. v. 16, p. 203-214.

Tiedemann, R., Sarnthein, M., and Stein, R., 1989, Climatic changes in the western Sahara: Aeolomarine sediment record of the last 8 million years: Proceedings of the Ocean Drilling Program, scientific results: College Station, Texas, Texas A\&M University, v. 108, p. 241-277.

Van Neer, W., and Uerpmann, H.P., 1989, Palacoecological significance of the Holocene faunal remains of the BOS missions, in Kuper, R., ed., Forschungen zur Umweltgeschichte der Ostsahara, v. 2 of Africa praehistorica: Köln, Heinrich-Barth Institut, p. 307-339.

Washington, W.M., and Meehl, G.A., 1989, Climate sensitivity due to increased $\mathrm{CO}_{2}$ : Experiments with a coupled atmosphere and ocean general circulation model: Climate Dynamics, v. 4, p. 1-38.

Watts, A., 1990, What is happening in the Greenhouse?: Yatching Monthly, May, p. $70-73$

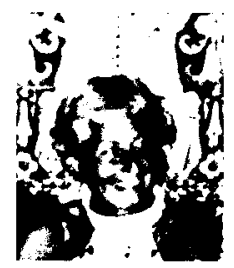

Dr. Nicole Petit-Maire, a Director of Research at Centre National de la Recherche Scientifique, France, has been working in the world deserts, mainly the Sahara, over the last 20 years, specializing in field research of past environmental change across the most desolate hyperarid areas. She is one among the first international scientists who probed, and realized with a large team of specialists in earth and biological sciences, multidisciplinary studies of continental climatic variations and who related her regional conclusions with global change (astronomical forcing, oceanic and ice cores, compare Episodes, 1986, v. 9). Since 1987, she has led IGCP Project 252 (Deserts: Past, Present, Future) and was elected one of the Vice Presidents of IUGS during the last International Geological Congress in Washington, D.C.. USA. 


\section{Publications of the International Union of Geoligical Sciences}

1. The Ordovician System in China Sheng Shen-Fu, 1980. US\$6.00. Stock Limited.

3. In search of the Paleogene Neogene boundary stratotype, Part 1-Potential boundary stratotype sections in Italy and Greece and a comparison with results from the deep sea. Available only from Giornale di Geologia, via Zamboni. 63-40128 Bologna, Italy. Not available from Episodes Office.

6. The Ordovician System in Australia, New Zealand, and Antarctica. B.D. Webby, et al., 1981. Correlation Chart and Explanatory Notes. 64 p., 1 table and 1 chart, US\$6.00.

7. An outline of the marine Triassic in China. Wang Yi-gang and others, 1981. 21 p., 2 tables and 1 map, US\$6.00.

8. The Ordovician System in Canada. C.R. Barnes, B.S. Norford, and David Skevington. Correlation Chart and Explanatory Notes. 27 p. . 2 tables and 1 chart, US\$6.00.

10. The Cambrian-Ordovician boundary-Sections, fossil distributions, and correlations. M.G. Bassett and W.T. Dean, (eds,), 1982. Published by National Museum of Wales, Geological Series 3, 227 p. Available from National Museum of Wales, Cathays Park. Cardiff. CF1 3NP. UK. $£ 17$ plus $£ 1.70$ for postage and packing, or from IUGS for US\$29.00. Not available from Episodes office.

11. The Ordovician System in southwestern Europe (France, Spain, and Portugal). W. Hamman, M. Robardet. and M. Romano, 1982. Correlation Chart and Explanatory Notes. 47 p., 1 figure and 1 chart, US\$7.50

12. The Ordovician System in the United States. Reuben J. Ross and others, 1982. Correlation Chart and
Explanatory Notes. 73 p., 4 figures, 1 table, and 3 charts, US\$10.00.

13. Southeast Asia-Tectonic framework, Earth resources, and regional geological programs. J.A. Katili and J.A. Reinemund, 1984. 68 p., US\$11.00.

14. Stratigraphy quo vadis? E. Seibold and J.D. Meulenkamp (eds.), 1984. Published as AAPG Studies in Geology No. $16,70 \mathrm{p}$. Available from IUGS for US\$11.50. Stock Limited.

15. The Cambrian System in the Near and Middle East. R. Wolfart, 1983. Correlation Chart and Explanatory Notes. 70 p., 1 figure and 1 four-color chart. US\$10.00.

16. The Carboniferous of the World, Volume 1-China, Korea, Japan and S.E. Asia. C. Martinez Diaz, R.H. Wagner, C.F. Winkler Prins, and L.F. Granados, 1983. Published by Instituto Geologico y Minero de Espana and Empresa Nacional Adaro de Investigaciones Mineras, S.A. Madrid, 245 p. Available from ENADIMSA Serrano 116, Madrid 6. Spain, or from IUGS for US $\$ 20.00$.

17. Petroleum resource assessment. C.D. Masters (ed.). 1984. An introduction to the methods and procedures of assessing petroleum resources. 157 p., US\$20.00.

18. Remote sensing for geological mapping. P. Teleki and C. Weber (eds.), 1984. Published as B.R.G.M. Document 82, 313 p. (including 25 color plates). Available from B.R.G.M., B.P. 6009 , 45060 Orleans Cedex. France. 300FF plus $30 \mathrm{FF}$ postage, or from IUGS for US\$33.00. Not available from Episodes Office.

19. The Cambrian System in Australia, Antarctica, and New Zealand. J. Shergold, J. Jago, R. Cooper and J. Laurie, 1985. Correlation Charts and Explanatory Notes. 101 p., 8 four-color charts, US\$15.00.
20. The Carboniferous of the World, Volume 2-Australia, Indian Subcontinent, South Africa, South America, and North Africa. C. Martinez Diaz, R.H. Wagner, C.F. Winkler and L.F. Granados (eds.) 1986. Published by Instituto Geologico y Minero de Espana and Empresa Nacional Adaro de Investigaciones Mineras, S.A., Madrid. 449 p. 37 plates. Available from ENADIMSA, Serrano 116, Madrid 6 . Spain for US $\$ 45$ plus US $\$ 5$ postage and handling, or from IUGS for US\$50.00. For air mail add US\$5 to North American addresses, US\$20 elsewhere.

21. The Ordovician System in Kazakhstan and middle Asia. I.F. Nikitin, M.K. Appolonov, D.T. Tzaj, V.G. Koroljov. A.I. Kim, M.V. Erina, N.M. Larin and A.N. Golikov, 1986. Correlation Charts and Explanatory Notes. 34 p., 3 figures and 2 charts. US $\$ 7.50$.

22. The Ordovician System in South America. F.G. Acenolaza and B. Baldis, 1987. Correlation Chart and Explanatory Notes. 68 p.. 3 plates. US\$11.50.

23. A global standard for the Silurian System. C.H. Holland and M.G.Bassett (eds.), 1989, 325 p. hardbound. Available from the National Museum of Wales, Cardiff, UK ( $£ 39.50$ plus postage of $£ 2.50$ UK or $£ .3 .50$ overseas; or from IUGS for US $\$ 72.00$ includuing postage.

24. The Cambrian System in eastern Asia. J.H. Shergold, A.R. Palmer (eds.), 1988. Correlation Chart and Explanatory Notes. 81 p., 4 charts, US\$18.00.

25. The Cambrian System on the East European Platform. J.H. Shergold, A. Yu. Rozanov, A.R. Palmer (eds.), 1990. Correlation Chart and Explanatory Notes. 73 p., I chart, US $\$ 13.00$. 26. The Ordovician System in most of Russian Asia. 1988. Correlation Charts and Explanatory Notes. 115 p.. 4 plates, US\$18.00.

Subscriptions to Episodes International Geoscience Magazine are US\$24.00 or $\$ 28.00$ Canadian. No discount is offered to Subscription Services. See the order form on the last page of this issue.

$\begin{array}{ll}\text { To order write to: } & \text { Episodes } \\ & \text { P.O. Box } 919 \\ & \text { Herndon, VA } 22070\end{array}$

or IUGS Secretariat Geological Survey - Norway

P.O. Box 3006, N-7001

Trondheim, Norway

Payments to Episodes for publications or subscriptions must be in US Dollars drawn on a US or Canadian bank, in Unesco coupons, or by VISA or MASTERCARD (Give account no., expiration date, and authorizing signature.) 